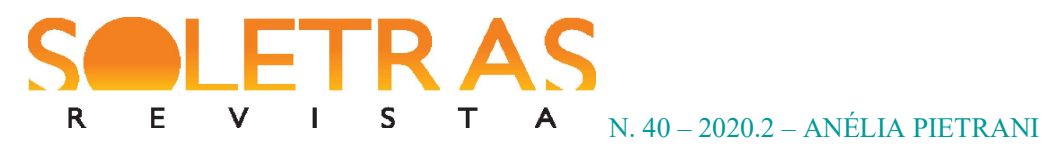

\title{
Um caso de sororidade literária: Narcisa Amália e Amália Figueiroa em jornais e revistas do século XIX
}

Anélia Pietrani ${ }^{1}$

\begin{abstract}
Resumo: A partir da recolha de textos publicados na imprensa do século XIX brasileiro sobre as poetas Narcisa Amália (1852-1924) e Amália Figueiroa (1845-1878), este artigo pretende examinar a recepção crítica das duas autoras nos jornais e nas revistas da época, de modo a reunir elementos sobre como elas eram apresentadas aos leitores ou às leitoras, como suas obras eram abordadas, que aspectos comuns às duas eram destacados, que relações eram estabelecidas entre suas obras e a experiência de cada poeta, que diferenças se evidenciam entre o ponto de vista de redatores masculinos e femininos. Além disso, pretende-se interpretar os textos críticos publicados por Narcisa Amália, dando destaque a seu ensaio sobre a poesia de Amália Figueiroa, como um modelo de sororidade literária em defesa da emancipação e educação da mulher. Busca-se, desse modo, propor reflexões que levem à discussão e compreensão do esquecimento ou apagamento das escritoras no cânone historiográfico da literatura brasileira.
\end{abstract}

Palavras-chave: Narcisa Amália. Amália Figueiroa. Poesia de autoria feminina. Recepção crítica. Cânone.

\section{Palavras iniciais}

Narcisa Amália (1852-1924) e Amália Figueiroa (1845-1878)² são apenas dois dos tantos nomes de escritoras que foram apagados do cânone historiográfico da literatura brasileira. Em certo sentido, o projeto de pesquisa coordenado por Zahidé Lupinacci Muzart, professora-pesquisadora da UFSC e integrante-fundadora do GT da Anpoll, "A mulher na literatura", que teve início nos anos 80 do século passado, deu conta de preencher essa lacuna e esse silêncio ao escavar as ruínas soterradas da história literária brasileira e revelar as significações do esquecimento ou apagamento de tantos nomes, seja por mudança dos padrões de gosto, seja por injunções sociais e políticas que sofreram essas mulheres. O longo trabalho de pesquisa culminou com a publicação, pela Editora Mulheres, de Florianópolis, de mais de três mil páginas dos três volumes de Escritoras brasileiras do século XIX, em 1999, 2004, 2009.

\footnotetext{
${ }^{1}$ Doutora em Letras - Literatura Comparada pela UFF (2005). Professora Associada de Literatura Brasileira da Faculdade de Letras - UFRJ e do Programa de Pós-Graduação em Letras Vernáculas - UFRJ. Rio de Janeiro, Brasil. E-mail: aneliapietrani@letras.ufrj.br Orcid: https://orcid.org/0000-0001-9907-8016

${ }^{2}$ Para fins de padronização, optamos neste ensaio por assim grafar os nomes de Narcisa Amália e Amália Figueiroa, tal como aparecem no livro Escritoras brasileiras do século XIX, embora a pesquisa em jornais da época tenha nos oferecido diferentes grafias: Narcisa Amalia, Narciza Amalia, Amalia Figueirôa, Amalia Figueroa.
} 


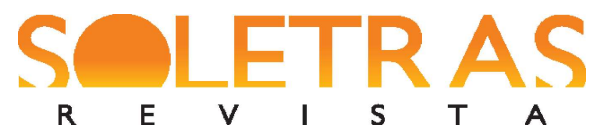

N. 40 - 2020.2 - ANÉLIA PIETRANI

Neste século XXI, já não se pode mais negar a presença quantitativa e qualitativa das escritoras na formação da literatura brasileira e na construção do pensamento crítico literário no Brasil.

Se os manuais de história literária esqueceram, os jornais assumem lugar indiscutível nessa revisão historiográfica: no espaço da visível folha amarelada e de um tempo que parece fugaz, a memória do que se pensou apagar se constrói em história cultural. Assim, a presença das duas escritoras na imprensa brasileira do século XIX passa por seu próprio modo de existência. Como os nomes Narcisa Amália e Amália Figueiroa existiram nos jornais; de que modo cada uma era referida; que autores escreviam sobre as duas; que gêneros textuais enfatizavam a sua produção poética; que lugar lhes cabia no espaço do jornal; que aspectos de suas obras eram destacados; que relação se estabelecia entre experiência poética e vida nos textos escritos sobre elas - eis algumas das questões que merecem ser colocadas para reflexão, ao serem pinçados recortes e páginas de jornais que indicam a presença e a existência de Narcisa Amália e Amália Figueiroa nos circuitos literários da imprensa do século XIX. Ainda que sob o risco da descrição metodológica, a recolha desse material e a tentativa de entendê-lo traduzem o propósito deste ensaio.

\section{Palavras sobre Narcisa Amália e Amália Figueiroa}

Se é difícil precisar a razão do "memoricídio feminino"3 na historiografia literária brasileira, tão difícil quanto é definir o momento em que seus nomes passaram a ser silenciados no panteão da literatura nacional. A certeza de quem investiga os nomes de poetisas, romancistas, cronistas, críticas literárias em jornais do século XIX é apenas a de que, durante esse intervalo, sua presença era marcante em muitos que circulavam em várias regiões do país e mesmo no exterior. Evidenciar essa presença significa também propor reflexões sobre "como" se dava essa presença de mulheres escritoras na imprensa.

A leitura atenta desse material denuncia algumas recorrências. O termo "poetisa", salvo engano, é o único empregado na época para se referir à mulher que escreve versos, sendo

\footnotetext{
${ }^{3}$ Em palestras e artigos, a professora Constância Lima Duarte (UFMG) tem empregado o termo "memoricídio" para expressar o apagamento deliberado de nossas primeiras escritoras na história das mulheres, promovido pelo corporativismo masculino de professores, editores, jornalistas - intelectuais, de maneira geral. Cf. o artigo "Escritoras mineiras presente! Anotações críticas", de sua autoria, publicado no livro Literatura mineira: trezentos anos, organizado por Jacyntho Lins Brandão (Belo Horizonte: BDMG Cultural, 2019).
} 
ignorado "a poeta", o substantivo comum de dois gêneros, hoje comumente preferido por muitas poetas. Os principais vocábulos empregados tanto sobre as poetisas quanto sobre sua poesia permeiam o campo semântico do que o senso comum costumava, e ainda costuma, vincular ao chamado universo feminino: flor e delicadeza parecem fazer par na recepção crítica de suas obras, eivadas sempre de "beleza" e "gênio", atributos que comumente se confundem com a pessoa e não exatamente se referem à poeta.

Bernardo Guimarães, por exemplo, em texto em defesa do voto feminino, publicado na seção "Folhetim", do jornal A Atualidade, de Ouro Preto, lamenta que o "sexo amável, formoso, risonho, vivo e inteligente aí fica a ver navios" ${ }^{4}$, ao que ainda acrescenta: "Só Zé João pode votar, e Narcisa Amália não pode!” (GUIMARÃES, 1878, p. 1)5. Embora se possa constatar que Amália Figueiroa compareça em menor número nos jornais da época, em comparação à fluminense Narcisa Amália, talvez por aquela residir no sul do país, ela também tem presença significativa nos jornais. Na seção "Variedade" da Gazeta de Notícias, em texto de duas colunas e meia, publicado em 1878, por ocasião da morte da poeta, assim escreve J. Palmella sobre Amália Figueiroa:

A voz da meiga poetisa, que de quando em quando abandonava timidamente o santuário doméstico para subir ao Parthenon Litterario e ali ser coroada de flores, ao som de frenéticos aplausos da mocidade portalegrense, calou-se para sempre!

As águas cristalinas do formoso Guaíba, quantas vezes espelharam aquele rosto moreno, aqueles olhos negros, aquelas tranças de azeviche; aquele corpo delicado e esbelto jamais tornarão a ver e ouvir os sons da lira da sua predileta cantora! (PALMELLA, 1878, p. 2).

A atitude de pensar a poeta por seus caracteres físicos parece ser recorrente em muitos críticos, o que é confirmado pelo próprio Palmella, quando, linhas seguintes às transcritas acima, ele faz uma crítica acirrada àquele "homem, esse chamado rei da criação," pródigo em somas consideráveis com animais e dançarinas, mas que não é capaz de abrir o cofre diante de uma Amália Figueiroa com seu "pequeno livro de poemas na mão" e incentivá-la à publicação. A isso ele ainda acrescenta: "E, quando aparece algum com ares de Mecenas, tem afinal mais

\footnotetext{
${ }^{4}$ Neste ensaio, todas as citações colhidas nos jornais da época tiveram sua ortografia atualizada.

${ }^{5}$ O mesmo texto de Bernardo Guimarães saiu publicado em A Reforma, do Rio de Janeiro, na seção "Variedades", sob o título "A eleição indireta", em 24 de setembro de 1878, p. 3-4.
} 
em vista representar o papel de Alcebíades, e assim erguer o falso turíbulo mais em honra da beleza e graça juvenis de mulher do que verdadeiro culto às suas virtudes e ao seu gênio" (PALMELLA, 1878, p. 2). Poderia ser evidente a autocrítica, se assim o percebesse quem assina o texto. Aliás, o autor ainda insiste, em várias momentos, em referir Amália Figueiroa como de "pouca cultura", com o fim de exaltar o exemplo dela em comparação às "modestas flores que vicejam no vale" (PALMELLA, 1878, p. 2). A comparação só vale mesmo para enriquecer o bosque de adjetivos floris dedicados à poetisa, porque é difícil crer de pouca cultura a tradutora de Victor Hugo, de quem Amália Figueiroa traduziu o poema "Canção"6. O texto, entre laudatório e necrológico, ainda termina com uma "coroa de perpétuas" e o epitáfio dedicado à "virgem poetisa" em sua "campa sagrada": "Homenagem ao gênio e à virtude da virgem poetisa rio-grandense, que sobre a terra teve o nome de Amália Figueiroa" (PALMELLA, 1878, p. 2).

D. Amália dos Passos Figueiroa, pelo que pudemos verificar, infelizmente esteve mais presente nos jornais por ocasião de seu falecimento. Múcio Teixeira, em 1884, publicou, no Diário do Brasil, um texto que, aparentemente, poderia fazer exceção aos obituários de Amália Figueiroa. Na verdade, o texto replicava outro de sua autoria, publicado no Rio-Grandense de Porto Alegre, em 28 de setembro de 1878, dia da morte da poeta. Apesar de transcrever alguns de seus poemas, toda a leitura é biográfica. Ao final, ainda cita um longo poema que compusera em homenagem à poetisa, terminando com este verso: "Levou para o céu a flor - da virgindade!" Afinal, o que ele teria a dizer sobre Amália Figueiroa, a não ser vê-la virgem no céu? O início do texto de Múcio Teixeira, aliás, é esta pergunta: “Que se há de dizer de uma virgem, pura e bela, que passou a cantar pela primavera da vida, com os grandes olhos negros e nostálgicos, voltados para o céu, a sua pátria ideal, e o pensamento a voar em cismas vaporosas?" (TEIXEIRA, 1884, p. 2). O resto do texto é um falar de si mesmo.

Mimoso e suas derivações, virgens belas, diminutivos e delicadezas parecem ser as mais frequentes recorrências quando o assunto é a mulher que estuda, lê e escreve. O Jornal da Tarde, de 11 de dezembro de 1871, noticia a chegada de Narcisa Amália à corte, vinda de Resende, onde mora com seu pai (é importante observar esse registro do jornal), para entregar a seu editor um "mimoso" livro de poesias. O semanário maranhense $O$ Domingo, de Arthur

\footnotetext{
6 A tradução de "Canção", feita por Amália Figueiroa, está publicada em Hugonianas, coletânea de poemas traduzidos de Victor Hugo, organizada por Múcio Teixeira em homenagem ao escritor francês, assim que soube de sua morte. Narcisa Amália também foi tradutora de Victor Hugo. Sua contribuição às Hugonianas aparece com sua tradução de "Os dois troféus".
} 
Azevedo, em 9 de março de 1873, ao transcrever e endossar as palavras do juiz prefaciador do livro recém-publicado de Narcisa Amália, admite que não lhe resta outra alternativa senão recomendar a leitura do livro de "mimosas poesias com o modesto nome de Nebulosas", "lisonjeira e delicadamente oferecido à redação" por sua autora. Na seção "Folhetim do Diário do Rio", do Diário do Rio de Janeiro, de 27 de novembro de 1870, ao agradecer o recebimento da tradução de Climas antigos, o espanto de Luiz Guimarães Júnior parece estar além do "livrinho vertido do francês pela Exma. Sra. Narcisa Amália", centrando-se na própria tradutora: "É uma coisa realmente bela de ver-se uma elegante senhora preencher os intervalos, que lhe deixam o crochet e os demais trabalhos domésticos, com estudos sérios, brilhantes, tendentes a aperfeiçoar a inteligência e depurar o espírito" (GUIMARÃES Jr., 1870, p. 1). E, como não poderia deixar de ser, se despede entre mimos: "Beijo as mãos da mimosíssima literata brasileira" (GUIMARÃES Jr., 1870, p. 1). Ainda no mesmo Diário, na mesma seção, agora em 10 de dezembro de 1871, o mesmo folhetinista dá nota da chegada da poetisa nestes modos: "Chama-se Narcisa Amália, a poetisa resendense, e só o nome basta, creio eu, para que o leitor dado a coisas literárias avalie o talento da mimosa cultora das musas nacionais" (GUIMARÃES Jr., 1871, p. 1). Façamos justiça, porém, a Luiz Guimarães Júnior, que, ao menos nesse texto, tece elogios à obra da poeta, apesar de não deixar de associá-los, metonimicamente, a sua autora:

Narcisa Amália, a quem dirijo este tratamento familiar, supinamente incivil para com uma senhora, mas próprio de um escritor a outro, é uma imaginação galante e arroubada, um coração harmonioso e espírito privilegiado a quem as sagradas musas presentearam com uma lira arrebatadora, simples como a flor e irradiante como o éter.

As suas estrofes saem-lhe da alma sem esforço, da mesma forma porque o aroma sai das úmidas caçoilas e a harmonia da tecla de um piano, que dedos descuidosos por acaso agitam.

Essa é que é a verdadeira poesia; essa é que é a verdadeira beleza; essa é que é a verdadeira mulher. Salve, musa brasileira! (GUIMARÃES Jr., 1871, p. 1).

Antes de poeta, a mulher é bela e musa. Dar a ela esse destaque é uma forma de contribuir para o apagamento histórico, que nem a lira de ouro ou a pena de ouro com que a Mocidade Acadêmica a brindou em 20 de setembro de 1874, pelas mãos do conselheiro 


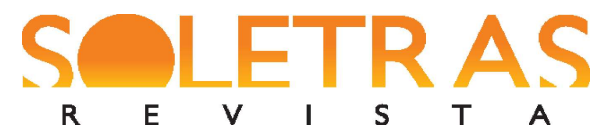

N. 40 - 2020.2 - ANÉLIA PIETRANI

Saldanha Marinho, puderam reverter. A comenda a ela conferida, com louvor, foi noticiada em O Resendense de 27 de setembro de 1874 e replicada em O Diário do Rio de Janeiro no dia seguinte. A poetisa se torna, assim, a palavra do universo feminino floril, delicado, mimoso. Como bem o sabemos, a criação dessa atmosfera pela crítica dirigida às mulheres que escrevem no século XIX e a insistência em associá-la ao perfil poético feminino acabou por implicar o valor pejorativo do termo "poetisa" e a recusa até hoje de seu emprego por muitas mulheres que escrevem poesia.

Injustiças também não deixam de ser feitas. Na seção "Crítica literária" do Diário do Rio de Janeiro, de 20 de setembro de 1878, José Palmella escreve sobre o livro de poemas Miosótis, de Teixeira de Mello, recém-publicado em 1877. Chama-nos a atenção que Palmella, ao mencionar o poema “Ambas" e compará-lo ao poema "Júlia e Augusta”, de Narcisa Amália, lança a absurda constatação sobre o texto de Narcisa: "parece ter-se inspirado no autor das Miosótis" (PALMELLA, 1878, p. 3). O falso problema é de simples solução. A publicação de Narcisa Amália é bem anterior à de Teixeira de Mello: data de cinco anos antes. ${ }^{7}$

Outra, no entanto, é a postura do periódico $O$ sexo feminino, fundado em Campanha das Princesas, Minas Gerais, em 1873, por Francisca Senhorinha da Motta Diniz, que também assumiu a função de redatora-chefe do jornal. Em 1875, ele é transferido para o Rio de Janeiro e suas principais pautas são intensificadas: a emancipação da mulher e a reivindicação do seu acesso à educação. A matéria de 11 de outubro de 1873 elenca atributos bem diferentes de Narcisa Amália. Seu "Noticiário", inclusive, termina com uma crítica mordaz ao "sexo contrário", destacando em itálico a certeza sobre a mulher que escreve:

Este periódico tem o indizível prazer de cientificar aos seus leitores que vai enumerar como colaboradora uma das mais hábeis que tem aparecido na imprensa diária da corte. A $\mathrm{Ex}^{\mathrm{a}}$. Sra . D. Narcisa Amália, poetisa distinta, literata não vulgar, talento transcendental, está acima de qualquer elogio que

\footnotetext{
7 Uma curiosidade sobre diálogos, quiçá plágios, envolvendo José Palmella e Narcisa Amália merece ser registrada: no texto de José Palmella sobre Amália Figueiroa, de 1878, já referido neste ensaio, restam indícios de um possível plágio praticado por Palmella de um texto de Narcisa, também sobre Amália Figueiroa, publicado por ela cinco anos antes. Comparem-se os dois trechos. Narcisa Amália escreve em 1873: "O homem que se intitula rei da criação - que depois de ter domado a natureza e os animais, subjuga a eletricidade e aplica-a ao seu bemestar, deve também dominar as suas paixões, e ser senhor de si próprio" (AMÁLIA, 1873, p. 4). José Palmella escreve depois, em 1878: "E o homem, esse chamado rei da criação, que tão pródigo é, às vezes para com os animais, gastando somas consideráveis, a bem do aperfeiçoamento das raças caninas, cavalares e muares" (PALMELLA, 1878, p. 2).
} 
a pena mais bem aparada possa tecer. Sua áurea inteligência se desenha no artigo com que mimoseou $O$ sexo feminino, e que vai publicado no lugar competente.

Chamamos para ele a atenção não somente do nosso sexo, mais ainda do sexo contrário, e muito principalmente dos retrógrados e pessimistas que não creem que as mulheres possam ser escritoras (DINIZ, 1873, p. 4. Grifo da redatora).

Mas quem ouvirá a voz de um jornal criado por mulheres? Esse é um ponto importante a se constatar: leitoras leem escritoras. Uma rápida vasculhada nos textos desses jornais da chamada "imprensa feminina" nos permite verificar que as próprias redatoras escolhem o termo "leitoras", no feminino, para referir-se a seu público. Além disso, a hipótese de Constância Lima Duarte (2016), em Imprensa feminista e feminina no Brasil: século XIX, parece bem pertinente. Para a professora da UFMG, que tem se dedicado, por longos anos, à investigação acurada da história das mulheres na literatura, o movimento feminista e a presença feminina na imprensa brasileira, talvez o caráter engajado de alguns textos tenha contribuído para a exclusão de muitas mulheres da historiografia literária. Aqui, podemos estender a hipótese aventada também aos periódicos com ideário mais engajado editados por mulheres e sua exclusão por um público mais amplo. Uma hipótese pode levar a outra.

Obviamente, os jornais de perfil conservador atuavam em seu papel contrário aos esforços de emancipação feminina. É o caso de $O$ apóstolo, periódico religioso, moral e doutrinário, consagrado aos interesses da religião e da sociedade. O título da chamada é “Liberdade da mulher”, estampada na primeira página em 17 de junho de 1887. O conteúdo, porém, reproduz a carta dirigida ao periódico, assinada pela Baronesa de Barueri, pseudônimo de uma escritora paulista que colaborava com o jornal, em protesto contra o protesto de Narcisa Amália publicado no n. 23 do Diário Mercantil. A dita Baronesa afirma não ter lido Michelet, citado por Narcisa no referido artigo, já que isso não é leitura para mulheres, mas afiança a má compreensão de Narcisa Amália do filósofo francês. Ela (?) é enfática: “não morro de amores por essa emancipação tão preconizada pela gentilíssima escritora, pois quero a mulher seja a rainha da casa, o anjo do lar, a protetora dos filhos" (O Apóstolo, 1887, p. 2), ao que acrescenta que não quer que a sociedade futura seja o prazo dado das femmes savant de Molière ou das Sabichonas de Narcisa Amália, e sim da Mulher-Forte da Bíblia.

A resposta de Narcisa Amália vem anos depois, na recém-proclamada república brasileira, no periódico A Família, de propriedade de Josefina Álvares de Azevedo, com o qual 


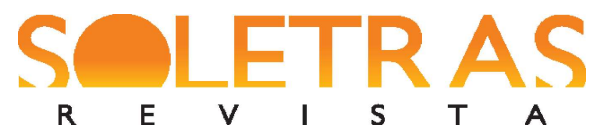

N. 40 - 2020.2 - ANÉLIA PIETRANI

Narcisa Amália também colaborou. Texto publicado em 31 de dezembro de 1889 dá o tom aos esforços de Narcisa Amália: "escritora de peregrino talento, variada instrução e indomável energia, criou para si um nome" (AZEVEDO, 1889, p. 6). A seguir, abre espaço para a voz de Narcisa, citando fragmentos de uma carta endereçada ao jornal, em que a escritora registra o seu pioneirismo no Brasil em tratar dos assuntos relacionados à emancipação feminina e acusa "os cavaleiros da imprensa paulista", que se valeram de "pseudos nomes feminis" para acusála de "atentado ao pudor da mãe de família" com suas leituras. Citando diretamente o jornal $O$ apóstolo, Narcisa rebate: "Espíritos másculos recearam por ventura que, a um meu aceno, suas esposas abandonassem o pot au feu e, tomando o bordão de peregrinas, marchassem em demanda da terra da emancipação" (apud AZEVEDO, 1889, p. 6). De fato, não é fácil ser leitora, muito menos leitora crítica, no Brasil do século XIX. Ela tem que enfrentar aqueles que se escondem atrás das imagens de mulher construídas pelos homens.

Parece que a hipótese de Constância Lima Duarte pode ser comprovada pelos caminhos que Narcisa Amália tomou ao circular nos jornais dos anos 80 do século XIX. Antes, ainda, porém, o silenciamento das mulheres escritoras já era gestado. Em O Novo Mundo, por exemplo, jornal fundado pelo advogado José Carlos Rodrigues e publicado em New York entre 1870 e 1879 em português, a menção aos livros de poemas de Narcisa Amália e Amália Figueiroa, no artigo "Poetas e poetisas", de 1873, ocupa o espaço do mesmo número que publica o famoso ensaio de Machado de Assis: "Notícia da atual literatura brasileira - instinto de nacionalidade”. Machado, convém ressaltar, não menciona em seu texto um único nome de escritora. Esse fato é imperdoável para um autor que pretendia dar notícias a leitores das Américas e da Europa sobre a literatura brasileira "atual". Tanto é ainda mais imperdoável, já que ele teve conhecimento, no ano anterior, da publicação de Nebulosas, de Narcisa Amália, sobre o qual, inclusive, escreveu uma resenha publicada na Semana Ilustrada, com data de 29 de dezembro de 1872, em que estampa este parágrafo lapidar:

Não sem receio abro um livro assinado por uma senhora. É certo que uma senhora pode poetar e filosofar, e muitas há que neste particular valem homens, e dos melhores. Mas não são vulgares as que trazem legítimos talentos, como não são raras as que apenas se pagam de uma duvidosa ou aparente disposição, sem nenhum outro dote literário que verdadeiramente os distinga (ASSIS, 1872, p. 6). 
O desapreço do mais importante escritor brasileiro do século XIX com relação às mulheres que escrevem se faz sentir em outro texto: "A nova geração", publicado na Revista Brasileira, em 1 de dezembro de 1879. Também esse texto de Machado, que pretende apresentar a "tentativa de poesia nova" da "produção recente" da década de 70, não faz menção a nenhuma poeta. Quando cita Narcisa Amália, o faz como prefaciadora do livro As flores do campo, de Ezequiel Freire, destacando a "pena delicada e fina" da "jovem e bela poetisa" (ASSIS, 1879, p. 406). Não foge ao ideário masculino sobre a escrita de mulheres, portanto.

Deixemos por ora o criador de Capitu e passemos à leitura do texto sobre os livros de Narcisa Amália e Amália Figueiroa da revista O Novo Mundo. Em 24 de março de 1873, assim o redator de "Poetas e poetisas" noticia os livros que lhe chegam do Brasil:

\begin{abstract}
Desta última vez, o paquete do Rio de Janeiro nos traz, além dos romances, nada menos de cinco volumes de versos, e, atendendo-se às minguadas produções que as senhoras têm contribuído à literatura nacional, há alguma coisa de extraordinário no fato, que folgamos de assinalar, que dois desses volumes são versos de duas jovens, uma, D. Narcisa Amália, do Rio de Janeiro, e a outra, D. Amália Figueiroa, do Rio Grande do Sul (RODRIGUES, 1873, p. 104).
\end{abstract}

O excerto faz alusão aos livros Nebulosas, de Narcisa Amália, e Crepúsculos, de Amália Figueiroa, ambos publicados em 1872. A surpresa do redator, ao deparar-se com dois livros assinados por duas poetisas, num conjunto de cinco volumes de versos recebidos, é evidente por dois fatos. Constatando que poucas mulheres publicavam, ele não deixa ainda de reiterar a concepção de pensamento comum ao que se espera dos ideários românticos: a contribuição à literatura nacional. O “extraordinário do fato”, em suas palavras, ainda é sustentado pela alusão à juventude das duas poetisas. Quando publicaram seus livros, Narcisa Amália tinha 20 anos, e Amália Figueiroa, 27. A pouca idade, no entanto, não deveria produzir efeito negativo, se considerarmos que os poetas românticos estabelecidos no cânone tiveram tempo médio inferior de vida. Entre as duas colunas do texto, o número 30 de O Novo Mundo estampa a gravura de uma das poetas, com cabelos encaracolados, escuros, puxados para trás e soltos pelas espáduas, de olhos baixos e boca carnuda, com parte superior do colo nua, pescoço cindido por colar da 
mesma cor escura do elegante vestido de mangas bufantes no antebraço e gola $\mathrm{V}$ com duplo babado plissado. Sob a gravura, os dizeres "D. Narcisa Amália, poetisa brasileira”. A mesma página traz outra gravura: "O túmulo de Eva", cuja presença não nos parece aleatória, se compreendida em consonância à leitura do texto "Poetas e poetisas".

Os trechos da matéria em que é feita a referência aos livros das duas poetisas parecem, à primeira vista, elogiosos. "Ramalhete" é o termo que o editor usa para referir-se ao conjunto de poemas de Nebulosas. Reiterando a nota sobre a míngua da produção poética de mulheres, no parágrafo anterior, a sentença que segue ao suposto elogio do ramalhete exalta Narcisa Amália não pela escrita dos poemas, mas porque eles "colocam a sua autora no alto da lista das poucas senhoras que no Brasil têm escrito alguma coisa" (RODRIGUES, 1873, p. 104). O importante é, portanto, que escreveram "alguma coisa", e a frase quase chega a beirar uma tautologia de falso elogio; afinal, se poucas escrevem, e Narcisa está no alto, que lugar é este? Logo no início do texto, por sinal, a evidência de que obras literárias não integram os gêneros "sérios” já aparecera bem marcada: "Temos falta de sábios e de instrutores do povo e da mocidade, e, pois, são raros os livros de estudos sérios e de educação elementar que nos chegam aqui do Brasil. À nossa mesa, porém, nunca faltam livros de poesias ou de romances" (RODRIGUES, 1873, p. 104).

A modulação de um discurso superficialmente elogioso permanece nos parágrafos seguintes do texto de $O$ Novo Mundo. Recusando que sua atenção se atenha à "delicadeza do sentimento" ou a "seu gênio", ele destaca a cultura revelada pelos versos da poetisa. A partir daí, a apologia à educação da mulher toma corpo, nos moldes do que considera o pensamento de "todo o mundo civilizado". Sua defesa, porém, se baseia na "fé [de] que haverá uma completa revolução na poesia”, em que a mulher deixaria sua hedionda escravidão para tornar-se ela mesma cantora, "não das pequenas paixões da vida, mas de Deus e de quanto há nobre e celebrável no Homem” (RODRIGUES, 1873, p. 104). A conjunção “mas” é sempre instigante. Se a palavra Homem com H maiúsculo leva-nos a pensar no sentido universalizante da poesia, não deixa, ao mesmo tempo, de criar um desconforto diante da constatação de Deus e Homem estarem em pé de igualdade, como ambições da mulher ou, na expressão usada pelo articulista, da "mais nobre criatura do Senhor". O romantismo, a valorização da subjetividade e a ênfase nos direitos da subjetividade individual pareciam não passar também pela valorização da subjetividade feminina; ao contrário, apesar do discurso liberal do autor de "Poetas e poetisas", 
em seu afã civilizatório, a preocupação com o controle da subjetividade feminina permanece. Previsível, ele não poderia encerrar a resenha de Nebulosas sem destacar o defeito de seus versos, ainda que não tenha fornecido ao leitor um exemplo sequer. No Brasil, segundo ele, só dois empregam impecavelmente os alexandrinos: Sr. Machado de Assis e o português Sr. A. de Souza Pinto.

Da produção editorial de Crepúsculos, de Amália Figueiroa, o redator devota "muito pouca consideração" e não poupa críticas logo de início: "mal impresso e pior encadernado em Porto Alegre" (RODRIGUES, 1873, p. 104). Para ele, o que sobressai "de simpatia" da obra é "um talento, muito inculto, sim, mas retemperado de verdadeiro sentimento poético" (RODRIGUES, 1873, p. 104). Com "imperfeições sem número", às poesias do livro, que ele chama "poemetos", não faltam os comuns feminis adjetivos "doce" e "linda". O redator não deixa de destacar a "verdadeira mágoa que a pequena coleção" lhe provoca, por a poetisa desprezar as consolações divinas. Não é possível afirmar tão categoricamente se essa transgressão o magoa exatamente por vir da pena de uma mulher, ainda que a expressão "idade de flores, hinos e estudos" possa ser boa insinuante para essa reflexão. Mas é certo que, do alto de sua sapiência masculina, não se poupa a dar à poetisa um conselho solar, bastante revelador da ideologia patriarcal dominante. Por divergir do melancólico e lunar crepúsculo poético de Amália Figueiroa, como se tentasse cravá-la culposamente no "leite romântico"8 já em vias de secar, o redator falseia o conselho em forma de três perguntas:

Para que serve sua invocação a Deus, que abre o volume, e os seus protestos de esperança e obediência, se a poetisa despreza as consolações que Ele lhe ministra? Para que esta persistência monótona em querer sofrer, ainda numa idade de flores, hinos e estudos? Não seria melhor que estes Crepúsculos fossem matutinos e precursores de um dia brilhante? (RODRIGUES, 1873, p. 104).

\footnotetext{
${ }^{8}$ A expressão aparece em, ao menos, dois textos de Machado de Assis: em crônica publicada em $A$ semana, de 25 de dezembro de 1892, e no ensaio crítico "A nova geração", publicado na Revista Brasileira, em 1 de dezembro de 1879. A crítica de Machado aos que chasqueiam o Romantismo sem ponderação e capacidade de reflexão acerca daquele período de formação também cabe aqui: "Mas não há só inadvertência naquele desdém dos moços; vejo aí também um pouco de ingratidão. A alguns deles, se é a musa nova que o amamenta, foi aquela grande moribunda que os gerou; e até os há que ainda cheiram ao puro leite romântico" (ASSIS, 1879, p. 373).
} 
Como não poderia deixar de ser em um texto intitulado "Poetas e poetisas", o redator também fala dos poetas, no caso, de apenas um poeta. Invertendo a primeiridade do título, mas sem deixar perder o protagonismo, o autor finaliza o artigo com a apresentação do livro Voos icários, de Sr. Rosendo Moniz. Em poucas linhas de um único parágrafo, o articulista dedica a ele os elogios guardados ao longo de sua leitura de Narcisa Amália e Amália Figueiroa. Sem tantas delongas, define-o com os mais vagos possíveis atributos: "livro mais substancial na forma e no fundo", "uma das melhores da coleção", "não achamos nada que não nos produzisse a impressão agradável, que nos faz toda a alma ardente e entusiasta de um jovem" (RODRIGUES, 1873, p. 106). Ser jovem poeta parece não ser mais pecado com a poesia de Moniz. Pecado, aliás, que a tinta do gravurista não deixa também de lembrar com o destaque, em metade da página, de "O túmulo de Eva", ajudando a enterrar de vez as evas da poesia.

\section{Palavras de Narcisa Amália sobre Amália Figueiroa - um caso de sororidade literária}

A participação de mulheres nos circuitos literários pelo jornal não se dá apenas como objeto de interesse para as seções de resenha ou os noticiários, tal como sugere a notícia replicada de $O$ Resendense, pelo Diário do Rio de Janeiro, em 21 de outubro de 1874, sobre a "Viagem de Sua Majestade, o Imperador" a Resende, onde pôde encontrar-se com o professor da escola pública e sua filha, "D. Narcisa Amália, a quem manifestou desejos de conhecer, e com quem conversou alguns momentos, pedindo-lhe uma de suas poesias inéditas" (GONZAGA, 1874, p. 2). Embora esse encontro com D. Pedro II tenha sido sempre muito destacado nas biografias da poeta como manifestação do grande desejo do Imperador em conhecer a poetisa de Resende, a forma com que o fato foi noticiado no referido jornal nos faz repensar essa sobrelevação. O episódio parece ter sido mais próximo do casual. Decerto que, em muitas referências na imprensa, a impressão que se tem é que as poetas estão presentes ora como musas inspiradoras, ora como bibelôs admirados. No entanto, o quadro que se pinta a respeito delas precisa ser compreendido em maior complexidade.

A presença das escritoras em revistas e periódicos tem outras extensões. Poemas de Narcisa Amália, e também de Amália Figueiroa, assim como suas traduções de poesia foram publicados em vários periódicos da época. A título de ilustração, registremos que a primeira 


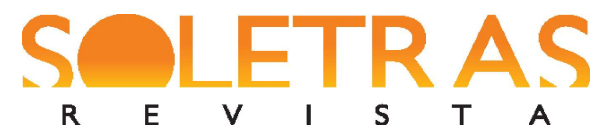

N. 40 - 2020.2 - ANÉLIA PIETRANI

estrofe $^{9}$ do poema "Sete de Setembro", de Narcisa Amália, é publicada repetidas vezes não só em diferentes jornais na mesma data, mas também em diferentes anos do dia sete de setembro, como epígrafe de textos laudatórios da data comemorativa da independência do Brasil. $\mathrm{O}$ curioso conto "Nelúmbia (legenda asiática)"10 , de Narcisa Amália, também é bom exemplo. Ele alcança repercussão praticamente em quase todo o Brasil entre os anos de 1873 e 1875 . Pelo que pudemos conferir na Hemeroteca Digital da Biblioteca Nacional ${ }^{11}$, o conto teve sua primeira publicação na seção "Folhetim da República", do n. 743 de A República (RJ), em 2223 de setembro de 1873. Sai também publicado na seção "Literatura" do Jornal de Pernambuco (PE), em 2 de outubro de 1873, e republicado no mesmo jornal em 23 de janeiro de 1875; na seção "Variedade" do n. 242 do Diário de Belém (PA), em 25 de outubro de 1873; no n. 228 de $A$ Nação (RJ) em 29 de outubro de 1873; no n. 11, de dezembro de 1874, da Lux! Revista Científico-Literária de Campos (RJ); no Jornal do Pará (PA), segmentado em duas partes, nos n. 39 e 40, de 19 e 20 de fevereiro de 1875, respectivamente; na seção "Variedade" do n. 217 de $O$ Conservador (SC), de 20 de março de 1875.

Além de suas publicações literárias em jornais, é também merecedora de destaque a contribuição ensaística de Narcisa Amália, "uma das primeiras mulheres, se não a primeira, a atuar como profissional de imprensa" (MACHADO, 2010, p. 319), como afirma Ubiratan Machado em A vida literária no Brasil durante o Romantismo, ao que acrescenta que Nebulosas “era a primeira obra de mulher cuja edição não era custeada pela autora. O mérito do livro justificou a audácia do editor Garnier" (MACHADO, 2010, p. 320). Uma das mais importantes pesquisadoras brasileiras sobre escritoras eclipsadas na historiografia literária brasileira e responsável pela republicação de Nebulosas pela Editora Gradiva, Anna Faedrich (2017) destaca, no posfácio à obra, diversos jornais em que Narcisa Amália publicou: “Astro Resendense, Monitor Campista, Echo Americano, O Espírito Santense, Gazeta de Campos, Correio Fluminense, Tymburibá, A República, Correio do Povo, O Fluminense etc." (FAEDRICH, 2017, p. 163). Destaque-se ainda sua participação também em periódicos do

\footnotetext{
9 "Salve! dia feliz, data sublime/ Que despertas o sacro amor da pátria/ Em nossos corações!/ Salve! aurora redentora que eternizas/ A era em que o Brasil entrara ovante/ No fórum das nações!" (AMÁLIA, 2017, p. 93)

${ }^{10} \mathrm{O}$ conto foi publicado em Um espelho para Narcisa - reflexos de uma voz romântica, de Christina Ramalho (1999), um dos trabalhos mais abrangentes e completos sobre a poeta e sua obra, e em e-book, em 2017, pela Ex! Editora, integrando a coleção "Primórdios do Fantástico Brasileiro", com organização de Alec Silva e Samuel Cardeal.

${ }^{11}$ https://bndigital.bn.gov.br/hemeroteca-digital/.
} 
exterior, como por exemplo na Artes e Letras de Lisboa, dirigida por Rangel de Lima. Em meio aos 27 colaboradores citados na folha de rosto da primeira edição da revista, lá aparece um único nome de mulher: "Narcisa (D.) Amália". O consistente ensaio "A música", publicado na edição de setembro de 1872, é digno de nota entre suas publicações na revista lisboeta. Dele trataremos, brevemente, como preâmbulo ao "caso de sororidade literária".

A poetisa rio-grandense inicia o ensaio "A música" abordando as semelhanças e variações entre poesia, pintura e música, e passa, a seguir, a desenvolver importante reflexão sobre o poder da música para eternizar a memória de um povo, bem como para possibilitar a equalização de diferenças sociais e históricas pelas emoções estéticas: "os infelizes párias da sorte", "o africano, crestado pelo sol ardente, extenuado pelos mais rudes trabalhos", "os filhos prediletos da fortuna” (AMÁLIA, 1872, p. 137). Para ela, “desde as mais remotas eras que a humanidade experimenta a doce influência da música” (AMÁLIA, 1872, p. 137).

Narcisa Amália abarca, a partir dessa reflexão introdutória em “A música”, uma tal amplidão temporal e espacial, que vem desde os bardos celtas até os românticos, desde Assur até Nápoles, desde a Itália, "pátria do luar e das serenadas", até o Brasil. E também amplifica em coletividade, sem dicotomias de gênero, os nomes de mulheres que atravessaram e atravessam a memória e a história viva da poesia e da música. Suas vozes e seus cantos ecoam na música do texto de Narcisa: Cornélia, a irmã de Tasso a embalá-lo com doces canções; Cassandra Fidelli e Christina de Pisani, as poetisas de Veneza, cujos anseios indefiníveis se apresentam nas barcarolas do gondoleiro; George Sand, "a loira soberana da inteligência" que realizou seus amores com o "moço poeta" Musset entre as cantilenas da ponte do Rialto; napolitanas a cantarem abraçadas a suas harpas; Tarquínia Molza, que compunha o acompanhamento para seus hinos e os cantava; a filha do Tintoreto, que tocava com perfeição diversos instrumentos; moços e moças a passearem e entoarem o coro à imagem da Madona que encontram no caminho.

Transportando-se da Itália para o Brasil, Narcisa precisa levantar "uma ponta do véu que oculta o santuário da família brasileira", para vislumbrar, no piano ou na harpa, "um meigo perfil de donzela, povoando de suaves harmonias o serão de seus pais" (AMÁLIA, 1872, p. 138). E ela não para aí: Heloisa Marechal, Carlos Gomes, Henrique Alves de Mesquita, Emílio do Lago, Luiza Leonardo são todos nomes de compositoras e compositores do Brasil elencados em seu compêndio da música brasileira da época, levando suas leitoras e seus leitores de hoje 
a questionar: por que, dentre as duas compositoras e os três compositores, apenas permaneceu na rica história da música brasileira o nome de Carlos Gomes?

Narcisa Amália também não deixará de reverenciar, em seu texto, o canto indígena, afinal "descendemos daqueles singelos filhos da natureza" (AMÁLIA, 1872, p. 138). E conclui seu ensaio: “A poesia prende e extasia, a pintura fascina e arrebata, mas a música só por si faz mais do que isso, porque, acima de tudo, abala o coração humano e é capaz de mudar a índole de todos os povos" (AMÁLIA, 1872, p. 138). Como vemos, a visão democrática com que a escritora feminista, abolicionista e republicana alimentou a poesia lírica de Nebulosas também está presente em seus ensaios. É na música de "todos os povos" que ela pensa. É de todas as gentes que se ocupa Narcisa Amália.

Essa ocupação com o coletivo, ou, melhor dizendo, essa preocupação com a defesa da democracia guiará os seus textos sobre a emancipação da mulher e os direitos à igualdade de gêneros na política, na filosofia, na ciência, na educação, na arte. Em seus ensaios críticos, como é bom exemplo "A música", sororidade parece ser a abordagem-chave, bem antes de a palavra existir como palavra-chave dos textos escritos pelas mulheres sobre as mulheres. Fala e ato se afinam nos textos de Narcisa Amália. Destes, um precisa ser destacado: trata-se do ensaio que ela escreveu sobre Amália Figueiroa ${ }^{12}$, publicado na seção "Literatura" de $A$ República, de maio de 1873, após a transcrição do poema "Cismas", de autoria da poeta que ela apresentará e sobre cuja poesia refletirá nas linhas desse "caso de sororidade literária" no século XIX brasileiro.

Este século que atravessamos, século que tem aluído o pedestal de tantos impérios. Que tantas conquistas têm proporcionado ao mundo científico, que tantas glórias têm celebrado e tanto clama pela emancipação da mulher, será um dia apontado como uma das épocas mais brilhantes da literatura brasileira (AMÁLIA, 1873, p. 3).

Como vemos, o primeiro parágrafo do texto já dá seu tom e anuncia a consciência crítica e competência analítica da autora em relação ao momento histórico e cultural. Dividido em dois

\footnotetext{
${ }^{12} \mathrm{O}$ mesmo texto saiu publicado um mês depois em $A$ Luz $(\mathrm{RJ})$, com o título "A poetisa rio-grandense: D. Amália Figueiroa".
} 
segmentos, o ensaio de Narcisa Amália é revelador, em sua primeira parte, do firme propósito da autora de ancorar-se na missão civilizatória em luta contra o absolutismo e o obscurantismo. No quadro que ela pinta, velhas instituições são aluídas, a mocidade crava olhos de águia no futuro, o progresso é torrente impetuosa, novos horizontes se rasgam à atividade humana. A autora sentencia: "Nestas circunstâncias, o poeta tem de desaparecer" (AMÁLIA, 1873, p. 3).

A frase é impactante e pode ter sido lida com surpresa, se pensarmos no escopo ideológico de gênero que prefigurava o senso comum da época acerca da voz de uma mulher no jornalismo e na poesia. A frase é, porém, altamente reveladora da consciência poética e política de Narcisa Amália, que completa: "o poeta tem de desaparecer; tem de deixar forçosamente as regiões fantásticas do idealismo para arremessar-se nas lutas" (AMÁLIA, 1873 , p. 3). O papel do poeta meramente contemplativo não tem mais lugar na poesia. E, a alguém que suponha que a poesia estaria com sua centelha sagrada perdida, Narcisa recorda sua fonte original - a mulher.

O texto assume, assim, o discurso emancipatório da mulher e elenca narrativas e nomes das grandes figuras femininas brasileiras e estrangeiras na história, nos mitos, na ciência, na filosofia, na arte: as vestais, a virgem de Tupã, Eva, Maria, Helena, Hipátia, as amazonas, Leonor, Lucrécia, Virgínia, Joana D’Arc, Beatriz, Delfina de Girardin, Harriett Stowe, Rita de Souza, Ângela do Amaral, Grata Hermelinda, Delfina da Cunha, Beatriz Brandão, George Sand, Henriqueta Renar, Nísia Floresta, Guiomar Torrezão, Maria Vaz de Carvalho, Amélia Janny, Júlia da Costa, Joana Tiburtina.

O propósito é quantitativo porque é preciso nomear a presença massiva de mulheres. $\mathrm{O}$ propósito é qualitativo, porque a denúncia da condição da mulher é visceral em Narcisa Amália, quando afirma que a mulher, largamente venerada no paganismo ou aureolada no cristianismo, “desce no Brasil, em pleno século XIX, quase à condição de escrava” (AMÁLIA, 1873, p. 3):

Que! à vítima imbele da máscula prepotência de todos os tempos será ainda negado entre nós um lugar nos festins da inteligência, um laurel nas conquistas da ciência?

Quais os direitos que tendes, ó homens sem coração, para julgá-la incapaz de estudos sérios e de ações magnânimas? (AMÁLIA, 1873, p. 3) 


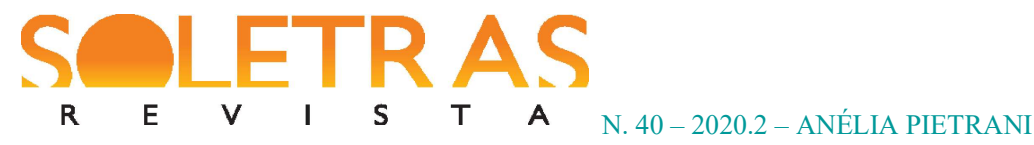

O tom não poderia ser menos eloquente nem menos enérgico, vindo da poeta que cantou em seus versos o desejo de liberdade da pátria, do africano, da mulher que sonha, da mulher que escreve. A primeira parte do texto ainda não está encerrada. Narcisa Amália denuncia "o desdém criminoso com que tem sido encarada a educação intelectual da mulher" (AMÁLIA, 1873, p. 3). Mantendo o tom ríspido do texto, reforça: “criminoso, sim", não sem antes fechar esta primeira parte do texto que celebra a esperança da civilização e do progresso, evidenciando a relação entre a mulher e a democracia.

A partir daí, o tom passa a ser, aparentemente, diferente. A segunda parte do texto de Narcisa Amália é totalmente dedicada à poesia de Amália Figueiroa. Agora, a linguagem da crítica literária está alinhada aos padrões românticos e eivada de termos como "templo sagrado das musas", "contemplando-lhe a fronte vasta, dourada pelos ardores do sol brasílio", "sulco luminoso de um cisma ideal", "ela vem do céu", "auroras esplêndidas do talento na terra" (AMÁLIA, 1873, p. 4), para citarmos alguns exemplos. Mas há um ponto importante a se destacar no ensaio, que o diferencia das demais crônicas e ensaios literários consultados: a preocupação de Narcisa Amália é com a leitura da poesia de Amália Figueiroa. Temas, ritmos, imagens, transcrições de poemas da escritora porto-alegrense compõem o ensaio da crítica literária fluminense. Não está em questão o detalhamento da vida em relação à obra da poeta. A obra responde às inquirições da ensaísta, e a poesia de Amália Figueiroa torna-se, assim, um campo de reflexão sobre o fazer literário e a imaginação criadora da mulher:

Só a lira vibrada por mãos femininas sabe o segredo de abalar assim todas as fibras do coração humano.

O sentimentalismo do homem, sempre artificial, tem em si alguma coisa de rude e áspero que não se harmoniza com os anseios vagos e indefinidos do coração da mulher.

(...)

Há mesmo alguma coisa de falso e de desagradável na lamentação que parte dos lábios masculinos (AMÁLIA, 1873, p. 4).

A referência à mulher no ensaio crítico de Narcisa Amália não é mais a mulher particularizada em Amália Figueiroa, "debruçada às margens do Guaíba". Refere-se à mulher universal, a mulher sempre grande, como disse na primeira parte do texto. Se o poeta deve desaparecer, como sentenciara anteriormente, a poesia permanecerá na palavra da mulher. E 
permanecerá porque uma mulher (“experimentamos por todos os talentos do nosso sexo"), admirada e sinceramente entusiasmada com a obra de outra mulher, trouxe-a ao conhecimento para promover a leitura da obra por outras mulheres ("procurar familiarizar mais entre as fluminenses o nome da jovem poetisa rio-grandense"). Assim, o tom das duas partes do ensaio se afinam.

Como Narcisa Amália dissera na primeira parte, a mulher abraça a grande causa da democracia. A poeta luta na própria poesia. Esse é o legado que a poeta de Nebulosas nos deixa nesse caso de sororidade literária, exemplificado por esse ensaio crítico, que é também revelador do projeto de pertencimento das mulheres a uma cidadania plena que Narcisa pensava construir pela escrita. No entanto, infelizmente se desfaz a esperança de Narcisa Amália com o progresso civilizatório contra o obscurantismo, manifestada no primeiro parágrafo do texto. Não pensara então a poeta que "nunca houve um monumento da cultura que não fosse também um monumento da barbárie” (BENJAMIN, 1994, p. 225), embora ela tivesse escrito em poesia o anátema infligido pela pátria a um corpo de mulher (que escreve):

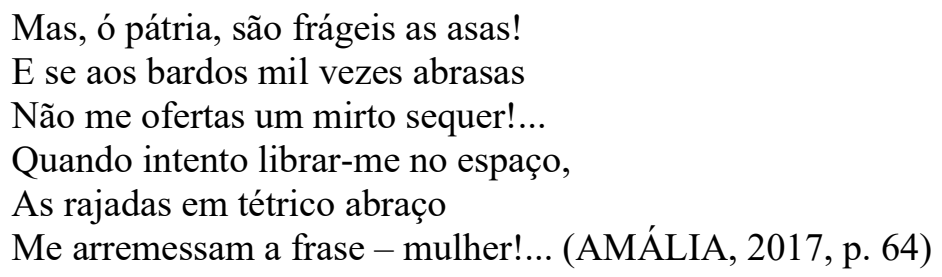

A linha da história artística e cultural eternizou a mulher como musa da pátria e da poesia, não como sua cantora. À mulher foi dada a condição passiva de ser escrita, não escritora. O belo sexo era apenas motivo poético, a musa inspiradora. Cumpria, pois, seu papel de deslocamento e sua condição de não pertencimento a um Estado-Nação. Durante muito tempo, a mulher não pôde integrar a comunidade política da nação, que era narrada por mãos de "máscula prepotência". Nem pôde também integrar, nesse sentido, a comunidade literária de uma nação ${ }^{13}$. O crime (sim, o crime) denunciado por Narcisa Amália foi, de fato, perpetrado

\footnotetext{
${ }^{13}$ Rita Terezinha Schmidt (2017) aborda consistentemente este tema em narrativas de autoria feminina do século XIX no artigo "Centro e margens: reflexões sobre a historiografia literária", publicado em Descentramentos/convergências: ensaios de crítica feminista.
} 


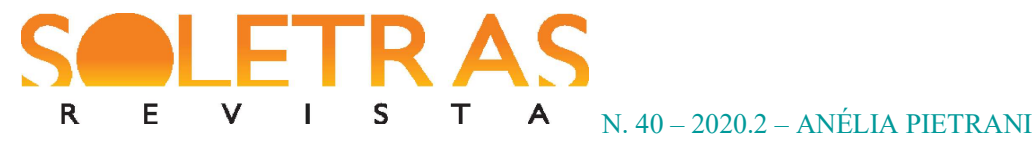

em prol de um falogocentrismo, que já tinha como garantia a absolvição autogendrada dos homens das leis e das letras.

\section{Referências}

AMÁLIA, Narcisa. Amália Figueiroa. A República. Rio de Janeiro, ano III, n. 640, p. 3-4, 19 e 20 mai. 1873. . A música. Artes e Letras. Lisboa, n. 9, p. 137-138, set. 1872.

Nacional, 2017. . Nebulosas. 2a . ed. Rio de Janeiro: Gradiva Editorial; Fundação Biblioteca . Nelúmbia. Org. Alec Silva e Samuel Cardeal. Brasil: Ex! Editora, 2017. [Coleção Primórdios do Fantástico Brasileiro], [E-book].

AZEVEDO, Arthur. Bibliografia. O Domingo. Maranhão, ano II, n. 9, p. 1-2, 9 mar 1873.

AZEVEDO. Josefina Álvares de. Narcisa Amália. A Família. Rio de Janeiro, ano 1, n. 44, p. 6, $31 \mathrm{dez} 1889$.

ASSIS, J. M. Machado de. A nova geração. Revista Brasileira. Rio de Janeiro, ano I, tomo II, p. 373-413, 1 dez. 1879.

. Notícia da atual literatura brasileira - Instinto de nacionalidade. $O$ Novo Mundo. New York, v. 3, n. 30, p. 107-108, 24 mar. 1873.

6-7, 29 dez. 1872.

. Nebulosas. Semana Ilustrada. Rio de Janeiro, ano XIII, n. 629, p.

BENJAMIN, Walter. Sobre o conceito da História. In: Magia e técnica, arte e política: ensaios sobre literatura e história da cultura. Trad. Sérgio Paulo Rouanet. $7^{\mathrm{a}}$. ed. São Paulo: Brasiliense, 1994, p. 222-232.

DINIZ, Francisca Senhorinha da Motta. Noticiário. O sexo feminino. Cidade da Campanha, MG, ano 1, n. 6, p. 4, 11 out. 1873.

DUARTE, Constância Lima e PEREIRA, Maria do Rosário A. Escritoras mineiras presente! Anotações críticas. In: BRANDÃO, Jacyntho Lins. Literatura mineira: trezentos anos. Belo Horizonte: BDMG Cultural, 2019, p. 34-48.

Horizonte: Autêntica, 2016.

. Imprensa feminista e feminina no Brasil: século XIX. Belo 


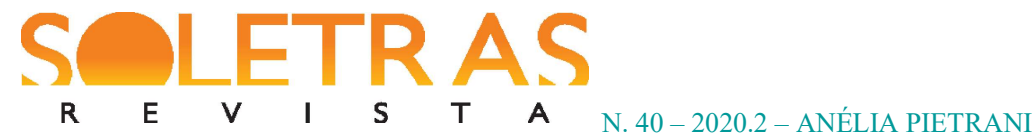

FAEDRICH, Anna. Posfácio: A lírica de Narcisa Amália - diálogos, intempéries e esquecimento. In: AMÁLIA, Narcisa. Nebulosas. $2^{\mathrm{a}}$. ed. Rio de Janeiro: Gradiva Editorial; Fundação Biblioteca Nacional, 2017, p. 157-189.

GONZAGA, F. C. Neves. Noticiário. Diário do Rio de Janeiro. Rio de Janeiro, ano 57, n. 291, p. 2, 21 out. 1874.

GUIMARÃES, Bernardo. Folhetim. A Atualidade. Ouro Preto, ano I, n. 78, p. 1, 6 set. 1878.

GUIMARÃES JR., Luiz. Revista do Domingo - Folhetim do Diário do Rio. Diário do Rio de Janeiro. Rio de Janeiro, ano 53, n. 328, p. 1, 27 nov. 1870.

. Revista do Domingo - Folhetim do Diário do Rio. Diário do Rio de Janeiro. Rio de Janeiro, ano 54, n. 339, p. 1, 10 dez. 1871.

HEMEROTECA Digital da Biblioteca Nacional. https://bndigital.bn.gov.br/hemerotecadigital/

Jornal da Tarde. Rio de Janeiro, ano III, n. 288, p. 1, 11 dez. 1871.

MACHADO, Ubiratan. A vida literária no Brasil durante o Romantismo. $2^{\mathrm{a}}$. ed. Rio de Janeiro: Tinta Negra Bazar Editorial, 2010.

MUZART, Zahidé Lupinacci (org.). Escritoras brasileiras do século XIX. Florianópolis: Editora Mulheres, 1999, 2004, 2009. 3v.

O apóstolo. São Paulo, ano 22, n. 66, p. 1-2, 17 jun. 1887.

PALMELLA, José. Amália Figueiroa - autora dos Crepúsculos. Gazeta de Notícias. Rio de Janeiro, ano IV, n. 358, p. 2, 29 dez. 1878.

Crítica literária - Miosótis (poesia) pelo dr. J. A. Teixeira de Mello. Diário do Rio de Janeiro. Rio de Janeiro, ano 61, n. 164, p. 3, 20 set. 1878.

RAMALHO, Christina. Um espelho para Narcisa - reflexos de uma voz romântica. Rio de Janeiro: Elo, 1999.

RODRIGUES, José Carlos. Poetas e poetisas. O Novo Mundo. New York, v. 3, n. 30, p. 104,106, 24 mar 1873.

SCHMIDT, Rita Terezinha. Centro e margens: reflexões sobre a historiografia literária. In: Descentramentos/convergências: ensaios de crítica feminista. Porto Alegre: Editora da UFRGS, 2017, p. 121-146.

TEIXEIRA, Múcio. Hugonianas. 3ª ed. Rio de Janeiro: Academia Brasileira de Letras, 2003. 


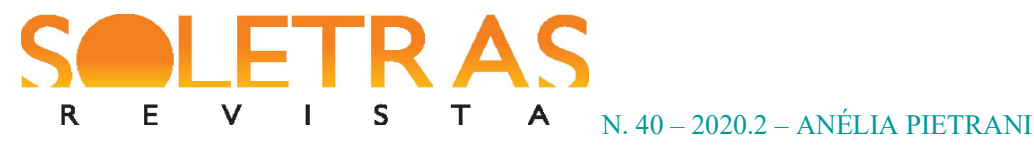

. Amália Figueiroa. Diário do Brasil. Rio de Janeiro, ano IV, n. 22, p. 2, 25

set 1884 .

\title{
A case of literary sorority: Narcisa Amália and Amália Figueiroa in 19th century newspapers and magazines
}

\begin{abstract}
Based on the collection of texts published in the 19th century Brazilian press about Narcisa Amália (1852-1924) and Amália Figueiroa (1845-1878), this paper aims to examine their critical reception, in order to gather elements concerned to the way they were presented to male or female readers, the approach of their works, their common aspects, the relationships between their works and the experience of each poet, the different points of view of male and female writers on both authors. In addition, the intention is to interpret the critical texts published by Narcisa Amália, highlighting her essay on the poetry of Amália Figueiroa, as a model of literary sorority in defense of women's emancipation and education. In this way, we propose reflections that lead to the discussion and understanding of women writers' oblivion or erasure in the historiographic canon of Brazilian literature.
\end{abstract}

Keywords: Narcisa Amália. Amália Figueiroa. Female poetry. Critical reception. Canon.

Recebido em: 31 de maio de 2020.

Acesso em: 22 de junho de 2020. 